SJ Quinney College of Law, University of Utah Utah Law Digital Commons

Utah Law Faculty Scholarship

Utah Law Scholarship

$3-2018$

\title{
Non-Discrimination and FRAND Commitments
}

Jorge L. Contreras

S.J. Quinney College of Law, University of Utah, jorge.contreras@law.utah.edu

Follow this and additional works at: https://dc.law.utah.edu/scholarship

Part of the Intellectual Property Law Commons

\section{Recommended Citation}

Contreras, Jorge L., "Non-Discrimination and FRAND Commitments" (2018). Utah Law Faculty Scholarship. 94.

https://dc.law.utah.edu/scholarship/94

This Article is brought to you for free and open access by the Utah Law Scholarship at Utah Law Digital Commons. It has been accepted for inclusion in Utah Law Faculty Scholarship by an authorized administrator of Utah Law Digital Commons. For more information, please contact

valeri.craigle@law.utah.edu. 


\title{
Non-Discrimination and FRAND Commitments
}

\author{
Jorge L. Contreras and Anne Layne-Farrar
}

A. Origins of Non-Discrimination Commitments In Standard-Setting 186

1. Non-Discrimination in the Law 186

2. Non-discrimination in Standards Development $\quad 187$

B. The Range of Contemporary SDO Non-Discrimination Commitments 189

C. Price Discrimination and Competition Law 190

1. Economic Approaches to Price Discrimination 191

2. Price Discrimination and Antitrust Law 193

D. Cases Addressing Non-Discrimination and FRAND 195

1. Legal Bases for Discrimination Claims 195

2. Discussion of Cases Alleging Improper Discrimination 195

E. Defining The Contours Of Non-Discrimination Covenants 198

1. FRAND Commitments and Uniformity of Terms 198

2. Non-Price Terms 198

3. Non-Discrimination as an Access Requirement (Level Discrimination) 200

4. Similarly Situated Licensees 202

5. Fairness and Non-discrimination 203

6. Non-discrimination over Time 205

$\begin{array}{ll}\text { 7. Non-discrimination and Transparency } & 207\end{array}$

A pledge to license standard essential patents (SEPs) on a non-discriminatory basis is a common element of SDO IPR Policies, part of the larger commitment to license on Fair, Reasonable, and Non-Discriminatory (FRAND) terms. In this chapter we consider what non-discrimination pledges imply for SDO member conduct. We review the basic variants of such pledges, how they may be informed by broader legal and economic definitions of discrimination, and recent cases and agency guidance interpreting such commitments. We conclude with open questions regarding the legal implications of non-discriminatory licensing pledges.

\section{A. ORIGINS OF NON-DISCRIMINATION COMMITMENTS IN STANDARD-SETTING}

1. Non-Discrimination in the Law

Prohibitions on discrimination of one kind or another pervade modern legal systems. They exist to prevent the unfair treatment of individuals on the basis of specified traits in arenas of 
social interaction including employment, housing, voting, free movement and access to facilities. ${ }^{1}$ Nondiscrimination principles also exist in international trade law (for example, requiring the like treatment of goods originating from all members of a treaty union) and the regulation of broadcast networks (e.g., so-called "equal access" and "network neutrality" requirements). Competition and antitrust law also embody principles of nondiscrimination, both as to unilateral conduct by dominant market participants ${ }^{2}$ and as to concerted action by competitors seeking to disadvantage others. ${ }^{3}$

As described in Chapter 9, contemporary FRAND commitments trace their origins to a series of U.S. antitrust enforcement actions in the early to mid-twentieth century. These actions sought to break up arrangements among groups of competitors that tended to restrict entry to markets and otherwise distort competition. The remedial orders entered upon conclusion of these cases generally sought to open the playing field to all market participants. For example, in U.S. v. Hartford-Empire, the Supreme Court approved an order requiring a group of competitors in the glassmaking industry to charge "uniform reasonable royalties ... without discrimination or restriction" on licenses of their glassmaking machinery patents. ${ }^{4}$

Prohibitions against discrimination also appear throughout the case law and agency guidance relating to patent pools. 5 In general, members of a patent pool can avoid the specter of antitrust liability by committing to license the pooled patents to all applicants on comparable terms, whether or not they may compete with the pool members. The broad availability of pooled patents on a nondiscriminatory basis was a key factor leading the U.S. Department of Justice (DOJ) to approve pooling arrangements for patents covering the MPEG-2, DVD and ${ }_{3} \mathrm{G}$ standards. ${ }^{6}$ For example, the DOJ explains in its business review letter concerning the 6C DVD patent pool that because the pool administrator "must license on a non-discriminatory basis to all interested parties, it cannot impose disadvantageous terms on competitors, let alone refuse to license to them altogether," thereby enhancing competition in the relevant market.7

\section{Non-Discrimination in Standards Development}

As early as 1932, the American Standards Association (ASA), predecessor to the American National Standards Institute (ANSI), began to permit the inclusion of patented technologies in standards so long as "monopolistic tendencies" were avoided. ${ }^{8}$ In 1959 the ASA first adopted

1 In the United States, these principles trace their roots to the Equal Protection Clause (Amendment 13) of the U.S. Constitution, enacted in 1865 in connection with the abolition of human slavery. Since then, statutes such as the Fair Housing Act (1968) and the [Equal Employment Act] have instantiated these principles in specific areas. In the European Union, Article 45 of the Treaty of Rome (1957) ensures nondiscrimination in employment on the basis of national origin and Article 157 ensures equal treatment of men and women in employment; the 1997 Treaty of Amsterdam (codified at Article 19(a) TFEU) extends individual nondiscrimination principles to race, ethnic origin, religion, disability, age and sexual orientation. Even international standards relating to corporate social responsibility establish principles for the elimination of discrimination against individuals (see ISO 26000).

$=$ See, e.g., Art. 102 (c) TFEU, an abuse of a dominant position may consist in "applying dissimilar conditions to equivalent transactions with other trading parties, thereby placing them at a competitive disadvantage."

3 See Chapter 9 and Contreras 2015b describing numerous U.S. remedial antitrust orders requiring nondiscriminatory patent licensing in order to redress anticompetitive collusion.

$4 \quad$ United States v. Hartford-Empire Co. (U.S. 1945, P.574).

5 For a description of how non-discriminatory licensing is handled by patent pool administrators including MPEG-LA, Sisvel and Via Licensing, see Gilbert (2011, 873-75).

6 See DOJ-MPEG-2; DOJ-3C DVD; DOJ-6C DVD; DOJ-3GPP; DOJ FTC 2007-Guidelines, 72.

DOJ-6C DVD at 14.

ASA 1932. See discussions at Contreras 2015b and Layne-Farrar 2014. 
a requirement that licenses of standards-essential patents by SDO participants be "reasonable." In 1970, ANSI added a requirement that such licenses be "demonstrably free of any unfair discrimination," thus establishing the basis for ANSI's current FRAND commitment. ${ }^{9}$

Though SDOs are reticent about the rationales underlying particular components of their IPR policies, ${ }^{10}$ commentators have advanced several theories regarding the function of nondiscrimination commitments in standard setting. At a basic level, it is believed that the availability of licenses to practice SEPs on a non-discriminatory basis is intended to promote the adoption of standards within an industry. That is, such a commitment assures market participants that if they incorporate a standardized technology into their products, they will not be disadvantaged in the marketplace vis-à-vis their competitors. As Lemley and McGowan frame the issue, "the general danger of allowing a private party to own intellectual property rights in an open standard is that the private party may at some point attempt to [distort competition], either by licensing it on discriminatory terms, by setting an unreasonable price for continued access, or simply by denying access (a license) altogether." ${ }^{11}$

A committee of the U.S. National Academies of Science expresses a similar view:

without FRAND, a patent owner might license its own customers and partners under terms that differ from those offered to a significant rival, either within or outside the bounds of antitrust law and other legal constraints. Thus, an objective of a FRAND licensing commitment is to avoid discriminatory licensing terms that disadvantage some licensees by imposing on them substantially larger royalties or more restrictive conditions in comparison with others. Indeed, this assurance of non-discrimination is fundamental to the weighing of benefits and costs that an industry participant makes when deciding whether to participate in an SSO or adopt a standard. ${ }^{12}$

And as long ago as 1992, as ETSI was debating its first patent policy, the European Commission emphasized the importance of non-discrimination in SEP licensing, particularly when standards embody mandatory governmental requirements:

Terms and conditions applied to participants and non-participants should not significantly discriminate against the latter. A fortiori where the standard-making body acts in an official or quasi-official standard-making capacity and where its standards are recognized and even made compulsory by virtue of legislation, access to the standard must be available to all without a precondition of membership of any organization. ${ }^{13}$

Others have argued that non-discrimination commitments reinforce the fair and reasonable aspects of the FRAND commitment. For example, Gilbert argues that the ND prong enables weaker firms to benefit from the bargaining power of stronger firms. ${ }^{14}$ Such leveraging could

9 USASI 1970, \$86. USASI was the successor to ASI and changed its name to ANSI in 1969. Nevertheless, the 1970 Operating Procedures, adopted after the name change to ANSI, still refer to USASI. The 1969 version of the USASI Operating Procedures used a similar, but less conventional, formulation, requiring "specified terms and conditions that are demonstrably [alternate text: reasonable and non-discriminatory] nonexclusionary." USASI 1969, \$84.

10 Though bucking that trend, the European Telecommunication Standards Institute (ETSI) has made public the meeting records covering its initial IPR policy debate in the early 1990s. These debates have been discussed in the literature including Iversen (2001), Bekkers et al. (2002), and Geradin (2014). It seems that the non-discriminatory aspects of FRAND, though embodied in ETSI's early policies, were not discussed in detail during this period. See also Chapter 9 .

"Lemley \& McGowan 1998, 760.

${ }_{12}$ NAS 2013, 53-54.

13 EC 1992, 19.

14 Gilbert 2011, 870. 
work to promote broad adoption of standards as well as market entry by smaller players. Gilbert also observes that non-discrimination covenants permit all licensees of a SEP to obtain equivalent terms whether they negotiate with the SEP holder before (ex ante) or after (ex post) adoption of the standard. ${ }^{5}$ However, as we discuss further below, depending on the circumstances, differences in timing can be justifications for differences in terms and conditions, so this observation is not absolute. Even so, the use of ex ante licenses to guide ex post license terms can work to eliminate the possibility that a SEP holder will be able to charge rates that include the licensee's switching costs and thus exceed the value of the patented technology. Carlton and Shampine extend this reasoning to argue that properly-scoped non-discrimination commitments can serve as important bulwarks against potential abusive or "hold-up" conduct by SEP holders ${ }^{16}$ even in the absence of ex ante licensing. ${ }^{17}$

On the negative side however, Gilbert observes that non-discrimination covenants may discourage the negotiation of low-royalty SEP licenses, even if warranted, as the SEP holder may fear the need to offer the same low rates to all licensees. ${ }^{18}$ This risk is akin to that associated with most favored licensee (MFL) clauses, which tend to keep prices high. ${ }^{19}$ Notably, ETSI's first interim patent policy in 1993 included such an MFL requirement, but this policy was quickly withdrawn in the face of substantial opposition to this and other controversial provisions. ${ }^{2 \circ}$

\section{B. THE RANGE OF CONTEMPORARY SDO NON-DISCRIMINATION COMMITMENTS}

As an initial matter, it is important to understand that SDO-based non-discrimination commitments come in a variety of forms, with different SDOs adopting different versions. The particular language employed in a non-discrimination pledge can be important to the interpretation of a SEP holder's commitment, so the first step in any case should be a review of the specific pledge made.

The most common form of non-discrimination commitment is the basic FRAND pledge to license any patents essential" for compliance with a standard on "fair, reasonable and non-discriminatory" terms. The International Organization for Standardization (ISO) offers a representative pledge. Its IPR Policy (which also covers the International Electrotechnical Commission (IEC)) includes the following terms: ${ }^{22}$

If the proposal is accepted on technical grounds, the originator shall ask any holder of such identified patent rights for a statement that the holder would be willing to negotiate worldwide licences under his rights with applicants throughout the world on reasonable and nondiscriminatory terms and conditions. Such negotiations are left to the parties concerned and are performed outside the ISO or IEC.

15 Id., 869-70.

${ }^{16}$ For a general discussion of the debate surrounding hold-up in standard-setting, see Chapter 7 .

${ }_{17}$ Carlton \& Shampine 2014, 3.

18 Gilbert 2011, 881.

19 See, e.g., Salop \& Morton 2013 ("[Most-favored nation clauses (MFNs)] can soften price competition and thereby allow firms to charge higher prices than they otherwise would. These are harmful collusive effects. MFNs also can have exclusionary effects by raising the costs of rivals or entrants that attempt to compete by negotiating lower prices from suppliers of critical inputs, or by pioneering a different business model.")

${ }_{20}$ See Chapter 9; Geradin 2013, Layne-Farrar 2013.

${ }^{21}$ For a discussion of essentiality in SDO licensing commitments, see Chapter 13.

22 ISO/IEC Directives 2015. 
The ETSI IPR Policy provides a similar variant, requiring that its patent-contributing members offer "an irrevocable undertaking" that the member is "prepared to grant irrevocable licences on fair, reasonable and non-discriminatory terms and conditions." ${ }^{23}$

Some SDOs go on to list specific rights that should be covered by a non-discriminatory license. For instance, the VITA Standards Organization (VSO) requires that licenses contain "nondiscriminatory terms to use, make, have made, market, import, offer to sell, and sell, and to otherwise directly or indirectly distribute products." ${ }^{24}$

The other common variation, exemplified by the ANSI Essential Requirements, calls for licensing that is "demonstrably free of unfair discrimination." 25 This form of pledge appears to recognize that "discrimination," which could be interpreted to mean any difference in price or licensing terms, raises concerns only when such differences are deemed "unfair."

All SDOs that are accredited by ANSI (more than 220 as of this writing) must comply with ANSI's Essential Requirements. Many ANSI-accredited SDOs, particularly those operating outside the ICT sector, simply adopt the language of ANSI's Essential Requirements verbatim. ${ }^{26}$ And even SDOs that have substantially developed their patent policies, such as the IEEE Standards Association, often adopt the ANSI-approved phrase "demonstrably free of any unfair discrimination." ${ }^{27}$

At least one SDO explicitly expands on this "unfair discrimination" language, observing that mere differences in price or other terms do not necessarily amount to prohibited discrimination. In particular, the Telecommunications Association (TIA) makes the following clarification in its IPR Guidelines:

The term "non-discriminatory" does not mean or imply that licensing terms must be the same for all applicants. Discrimination and difference are not the same. It is understood that the process of license negotiation and the components of consideration between parties can vary substantially yet be fair. The term "non-discriminatory" implies a standard of even-handedness. An example of conduct that would constitute discrimination is a willingness to license all applicants except for competitors of the licensor..$^{28}$

Below we discuss some of the economic and legal rationales for distinguishing among these variants.

\section{PRICE DISCRIMINATION AND COMPETITION LAW}

As described in Part B above, most SDO policies that impose non-discrimination commitments on their members provide few details regarding what is meant by "discrimination" and the types of discrimination that are prohibited. ${ }^{29}$ In this part, we explore various definitional aspects of the term discrimination and seek to tie these to the FRAND commitments and cases summarized above.

23 ETSI Directives 2015.

24 VITA 2015.

25 ANSI 2016, Sec. 3.3.1(b)(i). See also ABA 2007, 23 (discussing ANSI formulation of non-discrimination obligation).

26 Based on a 2012 review conducted by ANSI staff, approximately 92 percent of ANSI-accredited SDOs (250 of 272 policies reviewed) either incorporated the ANSI patent policy by reference into their own policies, or reprinted the ANSI policy as their own, with only minimal deviations (e.g., substituting the name of the SDO for "ANSI"). See Contreras 2015a.

27 IEEE-SA 2015, Sec. 6.2(b).

${ }_{28}$ Telecommunications Industry Association 2005.

29 See DOJ-FTC 2007, 47 n.77. 


\section{Economic Approaches to Price Discrimination}

In analyzing the meaning of discrimination, it is useful to begin with the economic concept of "price discrimination." The general economic definition of price discrimination hinges on production cost: price discrimination is defined as selling the same product to different customers for different prices when those differences are not justified by differences in the cost of production or supply. $3^{\circ}$

Because marginal production costs play little role in patent licensing, the economic definition for physical goods requires substantial modifications for application to IP. ${ }^{31}$ The development of patented technologies often involves high up-front R\&D costs and can involve high risks stemming from the fact that, in most cases, the up-front investments must be incurred without any guarantee that they will ever be recouped. On the other hand, once an invention is developed, the marginal cost of licensing tends to be relatively low (comprised of license monitoring costs, patent maintenance fees, and patent enforcement expenses paid as needed). For IP-related discrimination, economics therefore focuses on the effect of price differences on social welfare.

It is important to understand that price discrimination is not necessarily harmful; it can be neutral or even raise social welfare. The key here is the effect of price discrimination on output. A simple example helps to clarify the dynamic. Suppose there are two kinds of customers, both of whom equally desire to purchase a product, but one of whom is budget constrained. In order to sell to the budget constrained group, the seller would have to lower its price by half. The seller would exit the market if it could sell only at the low price that appeals to the budget constrained group, however, because its profits would be insufficient. If it must set a uniform price, then, it will charge a price at which only non-constrained customers buy. But without any restrictions on price (and assuming the seller can prevent arbitrage), the seller will price discriminate, lowering the price for the budget constrained customers only. In this case, price discrimination expands output and enables a group of buyers (budget constrained customers) to be served that would otherwise be "priced out" of the market..$^{2}$ Thus, price discrimination here raises consumer welfare: more consumers can buy at a price they are willing to pay and the non-constrained customers are not harmed by the price discrimination as they are paying exactly what they would have paid in the but-for world without price discrimination. Under these circumstances, price discrimination also raises total welfare: the seller sells more products, and even though profits are lower on sales to the constrained group, they are non-zero thereby increasing overall profits. It is only when output is reduced by price discrimination that welfare is lowered, and hence discrimination is harmful.

Economists categorize price discrimination as one of three types: first, second, and third degree. 33 Under first-degree (or perfect) price discrimination, the seller captures all revenue surplus by pricing each and every unit sold at exactly the customer's maximum willingness to pay for the good. Note that customers will still be willing to buy the good at this price, but no customer will earn rents from the transaction by paying less than the highest amount it would have been willing to pay. This form of price discrimination is relevant for monopoly sellers and requires a tremendous amount of information (the monopolist must know each and every customer's maximum valuation for the good or service). While it transfers consumer surplus to the producer, perfect discrimination also eliminates the deadweight loss associated with monopolies, meaning

\footnotetext{
30 Carlton \& Perloff 2004; Posner 2001, 79-80.

${ }_{31}$ Areeda \& Hovenkamp 2014, 9517 a; Posner 2001, 82.

${ }^{32}$ Schmalensee 1981; Klein \& Wiley 2003.

33 See generally Areeda \& Hovenkamp 2015, $\mathbf{\top}_{721}$; ; Pigou 1920, 275-89.
} 
that total welfare will be higher. But, as might be expected given information needs, first degree price discrimination is quite rare in practice.

Second-degree price discrimination is also known as nonlinear pricing or volume discounting. Here, prices vary by the quantity sold. So, for example, a single $12 \mathrm{oz}$. bottle of cola may sell for $\$ 1.75$, while an eight pack of 12 oz. bottles sells for around \$5, or around $\$ 0.62$ per bottle. Volume discounting is common throughout the economy and is typically viewed as efficient and welfare enhancing.

Third-degree price discrimination occurs when sellers price according to objective factors, such as location or observable consumer characteristics. The classic example is the movie theater that offers student discounts and cheaper tickets for shows before 6:00 pm. This type of price discrimination is also generally viewed as efficient and welfare enhancing. Running a theater requires certain fixed costs - renting the films, operating the physical structure, paying employees. Offering student discounts expands output to a group of consumers who are typically budget constrained and who would likely buy fewer movie tickets without the discount. Discounting prices for all customers before 6:00 pm increases off-peak use of the theater and helps to spread the fixed costs of operation across a larger sales base. Thus both of these practices potentially raise output and increase welfare.

The same factors relating to fixed costs are often at play for IP licensing. As discussed above, investments in R\&D must be made upfront and may entail significant risks. Being able to charge different licensing prices depending on the licensee's valuation of the patented technology can increase use of the technology (expand output) and can also help an innovator to cover its R\&D costs, which in turn can increase incentives to invest in R\&D in the first place. Thus we commonly see third-degree price discrimination in patent licensing, such as when a patent holder sets different rates for use of the patented technology in different end product markets, fields of use or geographical markets.

We also commonly see forms of volume discounting (second-degree price discrimination) in patent licensing. First, many industries practice portfolio licensing, in which a firm's entire set of patents related to a given technology (e.g., all patents related to the 802.11 Wi-Fi standard, whether or not technically essential to practice the standard) are licensed as a bundle. The price set for the portfolio license is almost always cheaper than the sum of the licensing price for each and every patent on an individual basis - if, in fact, the patent holder would even consider licensing the patents à la carte. ${ }^{34}$ Indeed, many portfolio licenses are priced on the basis of a handful of "representative" patents, with the remainder of the portfolio not explicitly priced, which is a kind of volume discount for licensing multiple patents in a single agreement.

A second form of volume discount applies to the units the royalty is applied to. That is, in arm's length agreements, large licensees, who are expected to sell significant quantities of licensed goods, typically pay a lower per unit royalty fee than smaller players. While the marginal cost factors behind traditional product volume discounts are not the driving force in patent license volume discounts, they do play some role. In particular, the licensor can earn a larger return on its R\&D from a single large licensee, than from multiple smaller licensees, as a result of lower aggregate negotiation and monitoring costs. More importantly, though, the practice has other sound economic justifications. Namely, a large licensee can act as a "market maker," ensuring the commercial success of the patented technology. This can be particularly important to establish the market for a new technology standard, as there is no guarantee that a standard will succeed in the marketplace even after SDO members spend years developing it.

34 Layne-Farrar \& Salinger 2016. 


\section{Price Discrimination and Antitrust Law}

While the economic definition of price discrimination is rooted in welfare, the legal definition derives from notions of fairness and equal treatment. 35 As noted above, price discrimination standing alone is not illegal, and has been recognized by the Supreme Court to occur in wellfunctioning competitive markets..$^{6}$ In order for price discrimination to result in a violation of U.S. antitrust law today, it must arise either from collusion among competitors (Sherman Act, Section 1), from exclusionary conduct indicating monopolization or attempted monopolization (Sherman Act, Section 2). ${ }^{37}$ Price discrimination, particularly when persistent and systematic, is often used as a means to identify market power. $3^{8}$ Price discrimination may also be an indication of collusive cartel activity. 39

Under U.S. law, in order to establish anticompetitive price discrimination, proof of output reduction, market foreclosure/competition softening, ${ }^{40}$ or SDO member capture (and distortion of a standard) must be provided. ${ }^{4}$ Observe that the antitrust laws today are meant to protect overall competition, not individual competitors. ${ }^{2}$ Showing that overall output is lower or that competition in the market as a whole is softer as a result of price discrimination is an important means of meeting that threshold. The third condition listed above - SDO member capture - warrants further explanation. The concern here is that preferential pricing offered to SDO members with sufficient clout to sway votes over the selection of technologies to include in a standard could distort the standard setting process. ${ }^{43}$ To the best of our knowledge, however, this concern remains a theoretical one as we are unaware of any antitrust cases making such an argument. Establishing proof of an anticompetitive effect can be direct, such as evidence of lost sales or profits resulting from price differentials, or inferential, such as a price difference over a sustained period of time involving a product that is resold in a highly competitive market. In either case, the plaintiff must prove, at a minimum, likely injury to competition. In order to obtain damages, the plaintiff needs to prove actual injury to competition.

The broad legal category of price discrimination is then parsed into three distinct types: primary, secondary, and tertiary line injuries. Primary line injury has two requirements: (1) the seller's price must fall below an appropriate measure of cost; and ( 2 ) the seller must be likely to recoup its investment in below-cost pricing by charging higher (implicitly supra-competitive) prices later on. In short, primary line price discrimination is the use of below-cost pricing to drive out competitors, after which prices are raised again, far above their original pre-predation levels. In order for this tactic to be successful (i.e., profitable), re-entry by the formerly foreclosed rivals must be difficult or impossible (e.g., the market must be protected by barriers to entry).

Secondary line injury relates to tilting the competitive playing field among buyers. Offering different prices to different buyers could place the buyer facing the higher price at a competitive disadvantage. Clearly for this injury to apply, favored and disfavored buyers must be in direct competition with one another. Finally, tertiary line injury involves price discrimination

35 Gifford \& Kudrle 2010.

${ }^{6}$ Illinois Tool Works Inc. v. Indep. Ink, Inc. (U.S. 2006, p.44).

37 See, generally, Woodcock (2017).

${ }^{38}$ Areeda \& Hovenkamp 2014, 9517 ; United States v. Grinnell Corp. (U.S. 1966, 566-67).

39 Posner 2001, 81 .

$4^{\circ}$ American Society of Mechanical Engineers, Inc. v. Hydrolevel Corp. (U.S. 1982).

${ }_{41}$ TruePosition, Inc. v. LM Ericsson Telephone Co. (E.D. Pa. 2012).

$4^{2}$ This represents a reversal of early antitrust theory, which did have the protection of competitors in mind. See Gifford \& Kudrle 2010, 1268.

43 Geradin et al. 2008. See also Layne-Farrar 2010. 
against product resellers, and as such is not relevant for our discussion of discriminatory patent licensing.

Despite the restrictive any "difference in price" legal metric, in regards to patent licensing, discrimination is commonly thought of in terms of licensee characteristics and hence does allow for differences in pricing across buyers. Offering different licensing terms to "similarly situated" licensees is generally viewed as discriminatory, as can be offering the same licensing terms to "differently situated" licensees. ${ }^{44}$ Determining whether two or more licensees are "similarly situated" then entails an assessment of relevant observable features across the licensees, including the firms' particular use of the licensed IP (which will affect valuations of that IP), firm size and expected revenues (relating to the extent of the use of the patented technology), competitive position in the relevant marketplace, the time span for which the patented technology is expected to remain valuable to licensees (which may be considerably shorter than the statutory term of the patent), and so forth. This list is not exhaustive and would need to be tailored to the precise patents and products at issue.

With so little guidance given by the courts as to the necessary elements of an antitrust claim for breach of a FRAND commitment, it is difficult to know what the evidentiary requirements would be. We can surmise, however, on the basis of other antitrust requirements, that a plaintiff would first need to establish that the SEP holder has market power. Even where "essential" patents are involved, though, we cannot assume market power. Patents do not automatically confer market power: different technical solutions may provide close substitutes. In many cases, compliance with a technical standard is measured by output (does the product perform as expected) and is not measured by input (does the product implement the steps specified by an SDO). As a result, firms can sometimes find different ways to comply with a standard other than following the specifications codified by the SDO, and thereby avoid infringing apparently "essential" patents. Moreover, standards can sometimes compete with one another (e.g., UMTS versus CDMA20oo), such that even if there were no alternative to a SEP within a given standard, a licensee could move to a different standard within the same market space (or a different product that end users view as a substitute within the same market). Finally, bargaining power of the SEP holder as compared to the licensee can matter too; the presence of strong licensees can moderate a SEP holder's market power. Assuming the market power threshold is met, the next step likely would be showing adverse effects on competition due to differential pricing. Specifically, it is likely that the court would require evidence of reduced output or softening competition.

Outside of the U.S. several jurisdictions have sought to address discriminatory conduct in relation to SEP licensing through express rules and policy guidelines. In the European Union, for example, a general focus of competition law is to prevent dominant firms from harming rivals through differential pricing and discounting practices. ${ }^{45}$ This general theme has been enforced through application of Article 82 (c) to a range of allegedly abusive discriminatory practices. ${ }^{4}$ Today, EU courts recognize two general types of price discrimination: when a dominant seller offers goods below its average variable cost, and when it offers goods below average total cost, but above average variable cost. The former is viewed as preemptively abusive, whereas the later can be justified by economic rationales and is therefor viewed as ambiguous and not preemptively abusive. 47

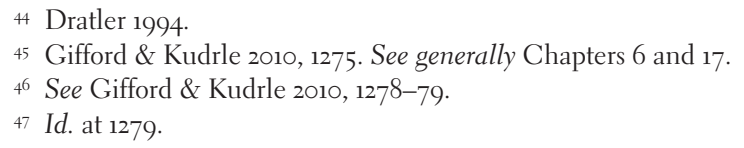


Korean competition authorities have sought to align Korean antitrust law with that of the U.S. and EU in the area of FRAND licensing. $4^{8}$ In 2014 the Korean Fair Trade Commission (KFTC) issued IPR Guidelines that enumerated several examples of abusive conduct, including "unfairly imposing discriminatory conditions when licensing standard essential patents." 49

Article 55 of the Chinese Antimonopoly Law (AML) deals with antitrust violations arising from the abuse of intellectual property. $5^{\circ}$ In written guidelines relating to the AML, the National Development and Reform Commission (NDRC) identifies discrimination against similarlysituated entities with respect to royalties, territory and license duration as potential abuses of dominant position.

\section{CASES ADDRESSING NON-DISCRIMINATION AND FRAND}

\section{Legal Bases for Discrimination Claims}

As noted by Landes and Posner (2003), "price discrimination is not in general unlawful." The focus of this chapter is the non-discrimination prong of FRAND commitments. While independent antitrust and competition law actions can be brought in the U.S. under the Sherman Act and FTC Act, ${ }^{51}$ and in the EU under TFEU Articles 81,82 and $102,5^{2}$ we do not focus on these actions except to the extent that they are based on an alleged violation of the non-discrimination prong of a pre-existing FRAND commitment. In addition, claims for breach of contract, promissory estoppel and fraud may be brought with respect to alleged breaches of FRAND commitments. 53 As the theory and procedure underlying each of these types of claims are discussed elsewhere in this volume, we focus solely on the particular features of such claims that are highlighted by alleged violations of a SEP holder's non-discrimination pledge.

\section{Discussion of Cases Alleging Improper Discrimination}

Below is a brief summary of illustrative cases in which claims were raised that a SEP holder violated its commitment to grant licenses on non-discriminatory terms. This summary does not purport to be comprehensive, and not all of the cases have been adjudicated to final decisions.

\section{a) U.S. Cases}

The issue of non-discrimination under FRAND commitments has come up in several U.S. cases. Charges of discriminatory SEP licensing in violation of Section 2 of the Sherman Act were brought in Broadcom v. Qualcomm (2007). In that case, the allegations included claims that Qualcomm was charging double royalties to manufacturers who used non-Qualcomm chipsets, and demanding overly broad cross-license rights from its licensees, among other things." 54 The eourt denied Qualeomm's motion dismiss, finding that a breach of a FRAND commitment could form an antitrust violation, but the case settled before

\footnotetext{
$4^{8}$ See Chapter 19.

49 KFTC 2014, \& III.5.A(5). See Chapter 19.

50 See Chapter 18.

${ }^{51}$ In addition, the Robinson-Patman Act (15 U.S.C. $\$ 13$ ) prohibits certain forms of price discrimination. Given that predatory pricing is seldom raised in cases involving FRAND commitments, and is unlikely to implicate the nondiscrimination prong of FRAND commitments, we do not discuss it here.

52 See Gifford \& Kudrle 2010, 1272-75.

53 See Chapter 11.

${ }^{54}$ Qualcomm (3rd Cir. 2007, 317-18).
} 
In In re Innovatio, discriminatory licensing in violation of a FRAND commitment was also alleged. In his decision, Judge Holderman held that "a RAND licensor such as Innovatio cannot discriminate between licensees on the basis of their position in the market," so any method for assessing FRAND should also account for consistent treatment of licensees. 55 Likewise, in 2015, an arbitration panel found that certain royalties charged by Ericsson to its licensee Huawei were inconsistent with the non-discrimination commitment that Ericsson made to ETSI. ${ }^{56}$

\section{b) Europe}

In Samsung v. Unwired Planet, 57 the UK Court of Appeal considered the effect of a FRAND non-discrimination covenant on SEPs transferred from Ericsson to Unwired Planet, a patent assertion entity (PAE), as part of a portfolio of over 2,80o patents and patent applications. In the case, Huawei argued that when Ericsson transferred certain SEPs to Unwired Planet, it failed to ensure that Unwired Planet's licenses of those patents be on terms consistent with those previously charged by Ericsson. In other words, Huawei argued that Unwired Planet should not be free, following the acquisition of Ericsson's SEPs, to charge rates and impose terms that may be non-discriminatory as compared to other licenses granted by Unwired Planet, but which fail to take into account licenses previously granted by Ericsson. The court agreed, holding that "Article 101 TFEU required the effective transfer to [Unwired Planet] of Ericsson's FRAND obligation so that [Unwired Planet] could not obtain more favourable terms from its licensees than Ericsson could itself have obtained," and that permitting this to occur would "allow Ericsson to circumvent its own FRAND obligations by increasing licence fees and weakening the competition between Ericsson and other users of its SEPs." ${ }^{58}$

The same dispute led to a subsequent decision in Unwired Planet v. Huawei (2017). There, the court held that the non-discrimination prong of ETSI's FRAND commitment does not create a "hard-edged" test in which a licensee may challenge an existing license solely on the basis that another similarly-situated licensee was granted a license at a lower rate, so long as the difference does not distort competition between the two licensees.59 As such, the court grounded its analysis of non-discrimination squarely in competition law, rather than the presumed contractual understanding of the parties and the ETSI participants that originated the policy giving rise to the relevant FRAND commitment.

\section{c) India}

In response to a number of patent infringement suits brought by Ericsson against Indian and Chinese mobile device manufacturers, ${ }^{60}$ the Competition Commission of India (CCI) initiated an investigation of Ericsson's licensing practices in India, including the firm's compliance with its FRAND obligations to ETSI. Among the licensing practices challenged by the CCI was Ericsson's charging royalties based on end product price, which resulted in different per unit fees for different licensees (i.e., depending on the price they charged for their end products). The CCI found that this pricing mechanism was discriminatory and in violation of Ericsson's

55 In re Innovatio IP Ventures, LLC Patent Litigation (N.D. Ill. 2013).

${ }_{56}^{6}$ Civil Minutes - General at 2, TCL Comms. v. Ericsson (C.D. Cal. 2016).

57 Samsung Elecs. Co. Ltd. v. Unwired Planet Inc., (UK Ct. Appeal, 2016). See also Chapter 13 (discussing the court's findings as to essentiality of Unwired Planet's patents).

${ }_{5}^{8} \mathrm{Id}$. at 550 .

59 Unwired Planet (2017) at $9481-502$ (this portion of the ruling is under appeal as of this writing). For more detailed discussions see Contreras 2017c and Layne-Farrar and Wong-Ervin 2017.

60 See Chapter 21 for a detailed discussion of FRAND litigation in India. 
FRAND commitment and Indian competition law. ${ }^{6}$ The decision, however, was overturned by the Delhi High Court, which found that Ericsson's licensing practices were consistent with its FRAND commitments. ${ }^{62}$ These cases remain in process as of this writing.

\section{d) China}

As discussed in greater detail in Chapter 18, in Huawei v. InterDigital Corp., Huawei alleged that InterDigital (IDC) discriminated against it by charging higher royalties for mobile terminals than it charged to other international vendors. In the case, the Shenzhen Intermediate People's Court found (and was affirmed by the Guangdong High People's Court), as a matter of contractual interpretation, that IDC violated its FRAND commitment by charging Huawei higher royalties than certain other vendors, and by requiring Huawei to grant royalty-free licenses of its own patents to IDC. In addition, the Shenzhen court found that IDC's discriminatory licensing practices with respect to Huawei, among other things, constituted a violation of the Chinese Antimonopoly Law.

\section{e) Korea}

In 2009, the Korean Fair Trade Commission (KFTC) brought an enforcement action against Qualcomm, finding that it was a dominant firm in both the markets for CDMA technology and chipsets. ${ }_{3}$ The KFTC went on to find that Qualcomm had restricted competition in the chipset market by charging discriminatorily high rates for CDMA SEPs to manufacturers who did not purchase Qualcomm chips. Specifically, the KFTC found that Qualcomm's conduct violated Article 3-2(1)(iii) of the Monopoly Regulation and Fair Trade Act ("MRFTA") by "unjustly hindering the business undertaking of others." ${ }_{4}$ The KFTC's ruling was affirmed by the Seoul High Court, which rejected Qualcomm's argument that its licensing program did not discriminate based on the identity of its licensees.

Interestingly, as Yi and Kim observe in Chapter 19, the 2009 Qualcomm decision may not shed much light on the interpretation of FRAND commitments in Korea, as the court found that Qualcomm's discriminatory conduct was a violation of antitrust law, rather than a failure to abide by its FRAND commitments. As Yi and Kim explain, "the Qualcomm decision established the competition law principle that the 'non-discrimination' prong of the FRAND pledge requires a vertically-integrated SEP owner not to favor its own component division against competing component makers with FRAND licenses...."

In 2016, the KFTC concluded another investigation of Qualcomm with a fine of nearly US\$1 billion and a remedial plan that required Qualcomm to grant FRAND licenses to any chipset manufacturer requesting such licenses, and to refrain from using the supply of chipsets as leverage in SEP licensing negotiations. ${ }^{65}$ As of this writing, Qualcomm has appealed this decision.

${ }^{61}$ Best It Worlds (India) Private Ltd. v Telefonaktiebolaget LM Ericsson, Case No. 4 of 2015, Competition Commission of India (12 May 2015); Intex Techs. (India) v Telefonaktiebolaget LM Ericsson, Case No. 76 of 2013, Competition Commission of India (16 January 2014); Micromax Informatics, Ltd v Telefonaktiebolaget LM Ericsson, Case No. 50 of 2013, Competition Commission of India (12 November 2013).

${ }_{62}$ Telefonaktiebolaget LM Ericsson v Micromax Informatics Ltd. and Mercury Electronics Ltd., High Court of Delhi at New Delhi, Court order of 12 March 2013, Docket no. C.S. (OS) 442/2013.

${ }_{3}$ For a more detailed discussion of this case, see Chapter 19.

${ }^{64}$ In a recent commentary note, the KFTC was applauded for "a very thorough analysis of the competitive impact of that discrimination on competitors that Qualcomm faced in downstream markets for modem and other types of chips" First 2016.

${ }^{65}$ See Chapter 19 . 


\section{E. DEFINING THE CONTOURS OF NON-DISCRIMINATION COVENANTS}

The cases described in Part D above deal primarily with straightforward issues concerning disparate royalty rates charged by SEP holders to standards implementers. A number of more complex issues also arise in the context of the non-discrimination commitment; these are discussed in this section.

\section{FRAND Commitments and Uniformity of Terms}

In a strict definitional sense, discrimination means treating different parties differently, and prohibitions on discrimination could be interpreted to prohibit any such differential treatment. But like the different economic treatment of price discrimination, most legal definitions of discrimination do not prohibit every form of differential treatment. For example, an employer cannot legally discriminate against job candidates on the basis of race, gender or religion, but can discriminate on the basis of experience, capability and prior references.

Likewise, most commentators agree that a commitment to "non-discriminatory" licensing does not mean that licenses must be granted to all applicants on identical terms. ${ }^{66}$ Yet beyond this general consensus, there is little agreement regarding the type and degree of uniformity that is required among licenses in order to comply with the non-discrimination prong of a FRAND obligation. The differences of opinion in this regard can be substantial. For example, Carlton and Shampine argue that "all 'similarly situated' firms should pay the same royalty rate." ${ }^{67}$ Mariniello, on the other hand, takes the view that FRAND is "the outcome of a bilateral hypothetical negotiation" and that FRAND license terms may thus "naturally var[y] amongst players." ${ }^{68}$

Gilbert likewise argues that requiring all licensees to pay identical per unit royalties would be both unfair and inefficient. ${ }^{69}$ Instead, he argues that similarly situated licensees should be offered the same schedule of royalties, which may include fixed fees, running royalties and volume discounts. Offering these options, he reasons, is procompetitive because "licensees will choose the combinations of price and quantity that give them the highest values." ${ }^{\circ}$ The NAS warns, however, that such menus of license choices could become discriminatory if they were structured, for example, to advantage only very large users of a standardized technology.71

\section{Non-Price Terms}

The reasonableness and non-discrimination prongs of the FRAND commitment apply not only to monetary royalty rates, but to all terms and conditions of SEP licensing agreements.

${ }^{66}$ See, e.g. Initial Determination of A.L.J. Shaw, In re Certain Wireless Devices with 3 G Capabilities and Components Thereof, No. 337-TA-800 at 432 (I.T.C. 2013) (the "non-discrimination" requirement of a FRAND commitment does not require that licensing terms for each individual manufacturer or competitor be uniform); ABA 2007, 22 (in practice, the terms of all FRAND licenses need not be identical); Carlton \& Shampine 2014, 10; Gilbert 2011, 872 ("it is artificial and counterproductive to impose a definition of non-discrimination that requires identical licensing terms for every licensee"); Layne-Farrar

${ }_{77}$ Carlton \& Shampine 2014, 16.

${ }_{68}^{6}$ Mariniello 2011, 532

${ }_{69}$ Gilbert 2011, 875 .

70 Id.

${ }^{71}$ NAS 2013, 65 . 
Non-monetary terms include (somewhat) quantifiable provisions such as duration, scope, field of use, territory, licensed affiliates, cross-licenses and grantbacks, as well as a range of difficult to quantify terms such as reciprocity, defensive suspension, indemnification and limitations of liability. ${ }^{72} \mathrm{~A}$ comparison of these non-monetary license terms is, in general, far more difficult than a comparison of royalty terms, as differences in language reflecting the give and take of contractual negotiation are difficult (if not sometimes) impossible to quantify and compare on an aggregated basis.

Given the difficulties of comparison, and the fact that most bilaterally-negotiated agreements will include different terms, how should a fact finder determine whether one licensee has been discriminated against? Must the comparison be conducted on a term-by-term basis, so that if the indemnity clause granted to Firm A is more favorable than that granted to Firm B, but the confidentiality provisions in Firm B's agreement are more favorable than those in Firm A's agreement, has discrimination occurred? Must the licensor give each licensee the benefit of every more favorable term granted to every other licensee, effecting a "race to the bottom" or super-most-favored licensee regime?

Such an approach could push licensors to become inflexible in the extreme, offering licenses on non-negotiable standardized forms only, much as licensing from patent pools is currently conducted. ${ }^{73}$ However, it is not clear that this lack of flexibility would work to the benefit of SEP licensees, many of whom have complex business requirements that make the customization of license agreements desirable.

What's more, even when contractual terms are facially identical, they may have significantly disparate effects on different licensees. This possibility was acknowledged by the arbitration panel in a recent dispute between Ericsson and Huawei, in which the panel recognized that "even identical terms can take on a different character between discriminatory and non-discriminatory depending on the nuances of the situation." 74 For example, grantback clauses that require a licensee to license its full patent portfolio relating to a standard to the SEP holder may have a much more serious impact on a technology developer that competes with the SEP holder than on a manufacturing firm that does not engage in independent technology development. Could a technology developer thus claim de facto discrimination on the basis of a contractual clause that is identical to that offered to all other licensees?

Given these complexities, some commentators have suggested that each SEP holder offer all licensees a uniform "cash only" price to license its SEPs. According to Kühn, Scott Morton and Shelanski $(2013,4)$, such an arrangement should serve as an "alternative to other pricing arrangements to aid in evaluation of the proposed license terms." Certainly, such an alternative would eliminate many difficulties of comparing dissimilar price and non-price terms of FRAND offers. However, this approach has its downside as well, given the efficiencies associated with firms settling all of their commercial dealings (or as many as possible) with a single contract negotiation. Even absent a "cash only" approach, it is likely that the non-discrimination analysis will in many cases remain focused largely on monetary terms of FRAND license agreements, with only those non-monetary terms of particular importance to the parties and circumstances at hand entering the analysis on an as needed basis.

${ }_{72}$ For a general discussion of these terms, see ABA (2007). See also Gilbert 2011, 875-77; NAS 2013, 66-67.

73 See ABA 2007, 22 (observing that offering a uniform set of license terms to all implementers is nondiscriminatory).

74 Civil Minutes - General at 9-10, TCL Comms. v. Ericsson, (C.D. Cal., May 26, 2016) (citing Arbitration Award in Ericsson v. Huawei (2015)). 


\section{Non-Discrimination as an Access Requirement (Level Discrimination)}

As discussed above, early U.S. remedial orders such as those in Terminal Railroad and HartfordEmpire used non-discrimination mandates to ensure broad market access to relevant resources and patented technologies. Thus, in dozens of these orders, patent holders were required to grant licenses to "all applicants" requesting such a license. 75 This requirement arose because the courts, and the DOJ that brought the suits, believed that open licensing to the marketplace would promote competition and remedy improper market concentration. ${ }^{6}$ For the reasons discussed above, it is likely that SDO FRAND commitments, in order to achieve goals of broad adoption of standards, also seek to maximize access to patents covering those standards. 77

This general view has been supported by courts including the U.S. Court of Appeals for the Ninth Circuit, which held in Microsoft v. Motorola that the SEP holder, in its declarations to the ITU, promised to "grant a license to an unrestricted number of applicants on a worldwide, non-discriminatory basis and on reasonable terms and conditions to use the patented material necessary" to practice the ITU standards. This language admits of no limitations as to who or how many applicants could receive a license (i.e., it specifies an "unrestricted number of applicants"). ${ }^{78}$ A similar commitment to universal access to SEPs was adopted by the IEEE in recent amendments to its intellectual property policy.79 Likewise, as noted above, in its 2016 remedial order against Qualcomm, the KFTC required that Qualcomm grant FRAND licenses under its SEPs to any component manufacturer requesting one. ${ }^{80}$

But others have argued that the "non-discrimination" prong of the FRAND commitment does not require SEP holders to offer licenses to every applicant that requests one, but only to avoid discrimination among the class of applicants that the SEP holder chooses to license. ${ }^{{ }^{8}}$ In other words, a SEP holder may wish to refuse to grant licenses (or to otherwise enforce its SEPs) certain classes of potential licensees, even if they have requested licenses.

This approach is largely motivated by the doctrine of patent exhaustion, ${ }^{82}$ under which a patent holder may collect a royalty only once per patented article. Here is the crux of the debate. Technology standards are typically implemented throughout a production chain, so that all component makers (chip fabricators, battery suppliers, software designers, etc.) must comply with the standard specifications in order to interoperate with one another and so that the end product as a whole (tablet, handset, laptop, DVD player, etc.) is compliant with the standard. In this regard, nondiscrimination in the standard context presents very different circumstances from the early remedial cases discussed above, which were focused on access by a largely uniform group of rivals (e.g., rail lines accessing a set a tracks) rather than disparate firms along a production chain accessing interoperability technology. Nevertheless, when a product embodying a patent is sold by an authorized licensee, the patent is "exhausted" and no further royalties can be collected, unless particular contractual measures are taken (and these remain uncertain

75 See Contreras 2015b.

${ }^{76}$ See, e.g., Hartford-Empire Co. v. United States (U.S. 1945, p.411) (purpose of decree was to "dissolve combination and prevent future combinations of like character"); United States v. Gen. Elec. Co., (General Electric II) (D.N.J. 1953, p.844) (decree intended to "check the intrusion of advantages thereby gained into the mechanics of competition in the lamp industry").

77 Carlton \& Shampine 2014, 546 ("all implementers of the standard should be offered licenses to the technology").

$7^{8}$ Microsoft Corp. v. Motorola, Inc. (9th Cir. 2012, p.884).

79 IEEE-SA 2015, Sec. 6.2(b).

8o See Chapter 19 [Korea].

${ }^{81}$ See, e.g., Crane 2010; Anne Layne-Farrar 2010b.

${ }^{82}$ Quanta Computer, Inc. v. LG Elecs., Inc. (U.S. 2008). 
in the wake of Quanta). Under strict patent exhaustion, the holder of a patent covering an aspect of a wireless communications standard could license either the manufacturer of the wireless chipset that physically implements that standard or the manufacturer of a smart phone that incorporates that chipset and realizes the patented technology. ${ }^{{ }_{3}}$ But once a license is granted to any link in the supply chain, the patent holder could be prevented by exhaustion from suing or extracting any royalty from any subsequent downstream purchaser of the chip. This would mean that if component makers are licensed, the full value of using the technology covered by the SEP, throughout the production chain, would need to be charged at the component level something that some industries are not structured to handle at present.

When license fees are restricted to the value conveyed to a component maker only, and licenses further down the product chain are prohibited, many SEP holders will not be able to obtain desired levels of compensation for the use of their technologies. It is thus most profitable for SEP holders to license as far "downstream" as possible (i.e., to end product manufacturers rather than chip or component vendors), in order to receive a royalty based on the relatively higher end product price, rather than the lower component price..$^{84}$ The current debate asks whether this approach unfairly discriminates against the chip and component vendors who are refused licenses.

SEP holders who refuse to license component vendors take the position that this refusal is permissible under their FRAND commitments. ${ }^{85}$ They argue that by licensing the downstream customers of component vendors, they have, in effect, "indirectly licensed" the component vendors, and that refusing to license component vendors does not discriminate against competitors. ${ }^{86}$ In other words, as long as all component are ignored, no one component maker placed at a competitive disadvantage. This approach was validated by the district court in Ericsson v. D-Link, which held that Ericsson did not violate a non-discrimination covenant made at IEEE by offering licenses only to vendors of "fully compliant" products and refusing to license chip and component vendors. ${ }^{87}$ Taking an opposite stance, however, IEEE amended its IPR policy following this decision to require that SEP holders make licenses available to all applicants. That being said, a number of SEP-holding IEEE members have refused to make licensing assurances under IEEE's new FRAND commitment, instead submitting "negative declarations" stating that they are unwilling to license their SEPs under IEEE's terms, and making known through other channels that they are prepared to license these SEPs on their own terms..$^{88}$

It is worth noting that requiring SEP holders to grant licenses at the component level would likely result in price changes for components in certain markets and a different approach to profit markups for affected component makers. That is, if SEP holders, for example in the wireless telecommunications market, were required to charge license fees at the component level,

${ }_{83}$ Some SEP holders have gone so far as to seek royalties from end users of standardized products. Most conspicuous among these was Innovatio, which sent demand letters seeking royalty payments from thousands of coffee shops, motels and other public venues offering use of public wireless routers. See Innovatio (N.D. Ill. 2013).

${ }_{4}$ As explained by a licensing executive for one large SEP holder, "we choose to license the patents as late in value chain as possible .... One big advantage with this strategy is also that it is likely that the royalty income will be higher since we calculate the royalty on a more expensive product." Dannelind 2010.

${ }^{85}$ See Ericsson v. D-Link (E.D. Tex. 2013, p. "80) ("Ericsson believed it complied with its RAND obligations because it did not discriminate against competitors").

${ }^{86}$ See Ericsson v. D-Link (E.D. Tex. 2013, p. "80) ("By licensing end product manufacturers, Ericsson believed it was indirectly licensing chip manufacturers.").

${ }^{87}$ See Ericsson v. D-Link (E.D. Tex. 2013, p. *82).

${ }^{88}$ See, e.g., Lloyd 2016; Katznelson 2016. 
they attempt to capture the full value contributed by the SEPs throughout the production chain from these component vendors (which in many cases would mean relatively high royalty rates, even greater than 100 percent prior to component industry pricing adjusting), with the understanding that the component maker would pass on both the patent rights and at least some portion of its royalty costs in its own pricing to downstream production levels. ${ }^{89}$

\section{Similarly Situated Licensees}

In United States v. United Shoe Machine Co., the court held that the defendant's discriminatory pricing constituted exclusionary conduct under Section 2 of the Sherman Act and ordered it to cease discriminating among customers "of the same general class." 90 In the same vein, several commentators and courts have reasoned that under FRAND commitments, discrimination as to royalty rates and other terms should be prohibited only as to "similarly situated" firms. ${ }^{91}$ In other words, if two firms differ significantly in terms of some set of characteristics, then offering them different license terms may be permissible. If this interpretation is correct, then another important definitional exercise is to specify what characteristics will qualify firms as similarly or differently situated.

One proposal to answer that question comes from Carlton and Shampine, who reason that similarly situated firms are those that, on an ex ante basis, "expect to obtain the same incremental value from the patented technology compared to the next best alternative available to be incorporated into the standard." 92 Thus, under their framework, "firms in different industries ... such as a handset manufacturer and a maker of wireless heart monitors, might make devices that obtain different incremental values from a patented technology and do not compete with one another, and thus can pay different rates." 93

As suggested earlier, royalties and other licensing terms may vary across licensees for a host of reasons. For instance, credit availability can affect license payment structure. Suppose Firm $\mathrm{A}$ and Firm B are both Wi-Fi router manufacturers with global sales, each with headquarters in Asia. Further assume that each holds roughly 15 percent of the relevant product market as measured by global sales revenues. Suppose, however, that Firm A has a large cash reserve while Firm B faces credit constraints. Even if a SEP holder provided both firms with identical opening license offers (along the lines of the license schedule noted above), it is highly likely that the license contracts concluded by the two licensees will differ. In particular, Firm A may wish to take advantage of its cash position by negotiating for an upfront lump-sum license. Because money received today is worth more than money received tomorrow, patent holders are typically willing to grant significant discounts to licensees making upfront lump sum license payments. Upfront payments also remove the risk of failure-to-pay and provide certainty over the payment amount (aiding in business planning), which can warrant further discounts. Firm B, in contrast, will not be in the position to pay for its license upfront and therefore cannot benefit from the discounts applied to such licenses. Instead, Firm B will likely prefer a license with ongoing (typically quarterly) royalty payments over the license term, which enables it to better manage its cash flow and to avoid the risk of overpayment should its sales of licensed products fall short of projected levels.

\footnotetext{
89 Layne-Farrar 2011; Layne-Farrar 2017.

$9 \circ$ United States v. United Shoe Machine Co. (1954, P.521).

${ }_{91}$ Gilbert 2011; Carlton \& Shampine 2013, 546; Ericsson v. TCL (2017).

$9^{2}$ Carlton \& Shampine 2014.

93 Carlton \& Shampine 2014, 17.
} 
Even if we assume that both licensees make identical infringing sales over the duration of the license, Firm A will end up paying less than firm B in the aggregate as a result of paying in advance. But, at least from an economic point of view, the SEP holder will not have unfairly discriminated between Firms A and B. In this scenario, Firm A is providing the SEP holder with a valuable payment in kind (the removal of several kinds of risk) that Firm B is unable to provide, hence Firm B must make up the difference in a higher explicit license fee.

Firms differing on multiple dimensions will only increase the rationale for differing licensing fees. For example, the presence of cross-licensing (another form of payment in kind) can lower explicit royalty payments, all else being equal. ${ }^{44} \mathrm{~A}$ firm with substantially more sales than a rival in the same downstream market may justifiably negotiate a volume discount, as explained above. Geographic differences in markets can also lead to licensing differences because end product demand and pricing may vary across locales. Differing product markets provide another justification. For example, Wi-Fi router and laptop manufacturers may both be interested in implementing the $\mathrm{Wi}$-Fi standard, but are likely to place very different valuations on a given set of SEPs, in light of different product prices and market dynamics relevant for each.95

\section{Faimess and Non-Discrimination}

As described by Gifford and Kudrle (2010), early legal rules prohibiting discriminatory treatment as to rail haulage charges and other commercial activities generally sought to target what were widely perceived to be unfair practices..$^{6}$ Antitrust laws also have their roots in norms of fairness, ${ }^{97}$ leading to early condemnation of discriminatory pricing by firms such as Standard Oil..$^{8}$ This aversion to unfair conduct found its way into the Federal Trade Commission Act of 1914, Section 5 of which expressly prohibits "unfair methods of competition." 99 Thus, as observed by Gifford and Kudrle, prior to the 1970s, "[l]awyers' historical preoccupation with fairness issues generated by price discrimination provided them with a very different perspective than economists, who were instead concerned with the welfare effects of discrimination." ${ }^{100}$ This emphasis on fairness faded, however, with the economic turn in antitrust enforcement in the 1970s, so that today, "fairness has largely disappeared as a factor in antitrust analysis," having been supplanted by a focus on efficiency and welfare. ${ }^{101}$

In parallel with the early legal focus, as noted above, beginning in the 1950 os several SDOs, led by ANSI, incorporated the notion of "unfair" discrimination in their IPR policies. Many SDOs today retain this emphasis on fairness, requiring that SEP licenses must be "demonstrably free of any unfair discrimination." Thus, an additional element is added to the non-discrimination analysis: whether or not any given discrimination among licensees is fair. If a certain discriminatory practice is found to be fair, then it may be permitted under the relevant FRAND policy. But if it is not fair, then it is prohibited. In assessing the fairness of potentially discriminatory practices by SEP holders, those that are grounded in sound economic rationales and affect similarly situated licensees in a similar manner are likely to be found to be fair. For example, the installment

94 Layne-Farrar zolob.

95 See, e.g. Teece \& Sherry 2016.

${ }^{6}$ Gifford \& Kudrle 2010, 1255-56, 1261.

97 Id. at 1256,1258 .

$9^{8} \mathrm{Id}$. at $1256-57$.

99 Federal Trade Commission Act of 1914, \&5 (codified at 15 U.S.C. $\int 45$ (2006)). See Gifford \& Kudrle 2010, $125^{8-59 .}$

${ }^{100}$ Gifford \& Kudrle 2010, 1259.

${ }^{101} \mathrm{Id}$. 
plans, volume discounts and credit for in-kind payments discussed above could be viewed as fair forms of discrimination.

Going further, commentators such as Swanson and Baumol (2005) argue that discrimination may be justified so long as it is efficient. They explain that "price discrimination helps a firm with fixed costs to recover its outlays and is sometimes necessary in order for a firm to recover those outlays." Why does such recovery matter? Because without at least some chance at earning a return, firms that cannot otherwise make up such returns through product or service sales may not invest in new innovations. Requiring uniform fees could thus prevent some licensees from ever getting a license, which would lower output and reduce SEP holders' expectations of recovering their upfront investments, which in turn would lower those investments and slow standards development. Accordingly, Swanson and Baumol reason that "royalties that are 'reasonable' for RAND purposes may be literally discriminatory given that such discrimination can be consistent with (and often can be compelled by) the existence of competition." These authors propose a parity pricing benchmark for assessing whether a vertically integrated SEP holder's rates are discriminatory for its downstream rival (the Efficient Component Pricing Rule, or ECPR model, as adopted from regulated landline telecommunications monopoly pricing).

The Swanson and Baumol focus on vertically integrated SEP holders reflects the view that it is firms with downstream operations as well as upstream patents that pose discrimination risks. Vertically integrated firms can have incentives to tilt the downstream market in their own favor, and could thus discriminate against downstream rivals through SEP licensing, placing downstream rivals at a disadvantage as compared to the transfer prices set for their own internal use of the patents by an end product division. On this theory, Hovencamp et al. (2005) conclude that "[a]n antitrust violation is even less likely where the intellectual property owner does not compete directly with the disfavored licensee; absent some showing of monopoly leveraging it is not clear what incentive the intellectual property owner would have to try to eliminate competition in the downstream market [through discriminatory licensing fees]." Making a similar point in the context of standard setting, Layne-Farrar (2010) observes that "[n]onintegrated firms will only be interested in anticompetitive licensing discrimination if it increases their total royalty payments, but often it is increased downstream competition that maximizes upstream royalty earnings."

The UK High Court in Unwired Planet v. Huawei, without expressly linking its holding to notions of fairness, adopts a competition-centric view when it rejects the idea of "hard-edged" non-discrimination and reasons that a violation of the ND prong of ETSI's FRAND commitment will be found only when a difference in pricing distorts competition between licensees. ${ }^{102}$

In light of the important role that differential patent licensing can play in recouping R\&D expenditures and expanding markets, Crane (2008) argues that "the 'nondiscriminatory' prong of the RAND commitment should be read narrowly to prohibit only discriminatory licensing to potential downstream rivals and not price discrimination more generally, else the RAND commitment turn into an inflexible commitment to license at identical terms to all potential licensees."

These authors and judges thus appear to advance the proposition that some discrimination is efficient and thereby "fair." In SDOs that prohibit only unfair discrimination, these arguments may hold some sway. One must ask, then, whether a fairness standard should also be read into FRAND commitments that do not recite this qualification. It is worth remembering that FRAND

\footnotetext{
${ }_{102}$ Unwired Planet (2017) at $\Upsilon_{4} 81-502$ (this portion of the ruling is under appeal as of this writing). See also Part D.2.b, supra.
} 
(fair, reasonable and nondiscriminatory) itself is framed in terms of fairness. Thus, among those SDOs adopting FRAND as opposed to RAND, even if discrimination is not expressly prohibited only if unfair, one could imbue both the reasonableness and nondiscrimination terms of FRAND with some baseline requirement of fairness, much as underlying law often implies a duty of good faith and fair dealing into contractual arrangements. This reading of "fair" as a modifier of both reasonableness and nondiscrimination in the FRAND formulation is certainly more useful than the typical reading, which is simply to treat "fair" as a superfluous synonym for "reasonable" bereft of any independent content. ${ }^{103}$ And if we are to take this step, then we may also wish to complete the circle and ask whether it is appropriate to imply this requirement of fairness even into SEP licensing commitments that are stated simply as RAND.

\section{Non-discrimination Over Time}

Another complex issue is how the passage of time affects a pledge not to discriminate. There are two aspects to the question of temporality associated with non-discrimination. The first is the effect of a discovery that the SEP holder discriminated against the licensee at the time the license was granted. The second is the effect of changing market conditions after a FRAND license has been granted.

Under the first scenario, the licensee subsequently discovers discrimination by the SEP holder at the time a license was granted (contemporaneous discrimination). This circumstance is made more likely by the general non-transparency of the SEP license negotiation process. ${ }^{104}$ That is, licensees seldom have verifiable information regarding other licenses granted by the SEP holder with whom they are negotiating. Without prior license term disclosure, the licensee cannot know, at the time that a license is granted, whether or not it is being discriminated against. Thus, even if the licensee is persuaded, based on its internal requirements and observable market factors, that the SEP holder's proposed royalty rate and other terms are fair and reasonable at the time of grant, it is impossible for the licensee to confirm that the SEP holder has complied with its non-discrimination commitment. Usually, the information necessary for the licensee to assess the SEP holder's non-discrimination remains confidential until it is leaked improperly or disclosed through litigation or arbitration discovery. Given this time lag, Gilbert reasons that non-discrimination covenants cannot achieve their purpose "unless FRAND can be interpreted to apply retroactively to any intellectual property that should have been disclosed ex ante."105 This approach is sensible and corresponds with generally accepted tort liability principles relating to the discovery of past wrongful acts.

The second scenario is more complex. It involves a license that was granted by the SEP holder in full compliance with its FRAND obligations, but which, through the passage of time and changing market conditions, is no longer as favorable to the licensee as other licenses being granted by the SEP holder. Thus, an early licensee could pay a higher royalty rate than later licensees. In this case, has the SEP holder impermissibly discriminated against the early licensee?

One way to think about this question is to look at the "reasonableness" prong of the FRAND commitment. A given royalty rate offered prior to the adoption of a new standard may no longer be reasonable many years later, when the market and technology have advanced significantly

\footnotetext{
${ }^{103}$ See DOJ-PTO 2013

104 See Part E.7, infra.

${ }_{105}$ Gilbert 2011, 879 .
} 
(possibly making a higher royalty reasonable) or the standardized technology has moved toward obsolescence (possibly making a lower royalty reasonable). These issues are far from theoretical, as many standards are not static technology mandates but evolving guidelines. For example, work on the most popular global digital mobile phone standard first began in the early 1980s, with commercial release of $\mathrm{GSM}\left({ }_{2} \mathrm{G}\right)$ in the mid to late 1990s. Commercial release of the ${ }_{3} \mathrm{G}$ WCDMA evolution of that standard occurred in the early zooos, and the first commercial rollout of $4 \mathrm{G}$ LTE was in 2009. Development of $5 \mathrm{G}$ is currently under way. Later generations of a technology standard tend to build on prior generations, and for consumers' sake SDO members tend to place a high premium on backward compatibility. As a result, patents essential to early standards are likely to have at least some value for later generations (though that value may diminish over time). On the one hand, in light of the dynamic properties of standard development, FRAND valuations should evolve over time as well, to match changing market conditions. On the other hand, license agreements are contracts with specified durations. It would eviscerate the many well-recognized benefits of contracting and business certainty if agreed upon FRAND terms in a given license agreement were not honored. As a practical matter, we do not want to create a legal regime in which FRAND is an ever-shifting concept, such that parties cannot count on contractual certainty.

Yet another complication arises from how risk can change over time. In particular, in the early period of a standard's rollout, commercial success may be far from certain. Indeed, many standards fail in the marketplace. SEP holders may wish to give early licensees lower royalty rates in order to encourage uptake of the standard, making commercial success more likely. Later implementers, who enter the market only after others have established the commercial viability of a standard, naturally take less risk than the early licensees.

One could thus take the position that the royalty rate agreed by a SEP holder and a licensee in a signed license agreement should not be altered due to the passage of time, no matter what changes occur in the marketplace, so long as the original license offer complied with the SEP holder's FRAND commitments. This view is further supported by the fact that a license agreement's duration is a negotiated factor: parties wanting stability or those worried about rising rates can voluntarily opt for longer contracts; those worried about falling rates can opt for shorter-term contracts. This position is not universally accepted, however. Shampine (2016) argues that an existing licensee may, in fact, be justified in seeking a lower royalty rate if it discovers that the licensor has subsequently offered lower royalty rates to its competitors. Yet if non-discrimination implies that already-granted licenses may be adjusted retroactively as new information about contemporaneous licenses comes to light, the non-discrimination covenant begins to look like a "most-favored-licensee" commitment, which assures a licensee that the licensor will not, during the term of the MFL commitment, grant a more favorable license to another party. ${ }^{106}$

But even if existing licenses are not changed due to later circumstances or discoveries, how should new license offers be treated if they are on terms different than earlier license grants? Has impermissible discrimination occurred if later licensees are offered at higher rates than earlier licensees? In one sense, this scenario, which gives ex post licensees the benefit of ex

\footnotetext{
${ }^{106}$ See Carlton \& Shampine 2013, 551-52 (proposing the use of MFL clauses to ensure that royalty rates decrease uniformly across FRAND licenses). MFL clauses are often viewed as more powerful than non-discrimination covenants precisely because of their retroactive effect. But they also have anticompetitive aspects in that they discourage discounts, tend to keep prices high, and may encourage licensors to shift to rigid uniform licensing.
} 
ante negotiation, is precisely what the non-discrimination covenant is intended to prevent. ${ }^{107}$ That is, general consensus has emerged that a good benchmark for what a FRAND rate is for a given set of SEPs is the licensing fee (and related terms and conditions) that those SEPs could have commanded during the development of the standard, when they were likely competing with other technologies for inclusion in the standard (ex ante). The competition and lack of any possible technology lock-in render these early rates reflective of market valuations and are free of holdup costs. But if FRAND valuations can increase over time, that progression will need to be accounted for in later licensing agreements, which reduces the comparability of early license agreements and again makes discrimination assessments more difficult. ${ }^{108}$

As a practical matter, one solution may be to reassess FRAND rates only when a license agreement expires or is up for renewal, with the understanding that what was FRAND at the time the prior contract was signed may or may not, depending on the circumstances, still be considered FRAND for a new license at the time of renewal. ${ }^{109}$ Naturally, this dynamic makes determining whether rates are discriminatory more difficult, because it means that comparable licenses - the bedrock of reasonable royalty assessments - may be in need of subjective modification.

\section{Non-Discrimination and Transparency}

As argued by Gilbert (2011), the enforcement of a non-discrimination commitment necessarily requires that the beneficiary of such a covenant have some information regarding the terms of licenses granted to others. Without this information, it is impossible for the licensee (or anyone else) to determine whether discrimination has occurred except during litigation or arbitration, when confidential discovery reveals relevant prior agreements. As several manufacturers of standardized products recently complained, “the 'non-discriminatory' part of 'FRAND' commitments could not possibly be enforced given the current lack of information about licensing terms." ${ }^{110}$ Though calls for greater transparency in SEP licensing have been made, primarily , there are no serious SDO or governmental initiatives under way to achieve these goals. Such transparency could be achieved either through the advance (ex ante) disclosure of a SEP holder's "standard" licensing terms and rates, or through disclosure of terms in concluded licenses. In both of these cases, the identity of the licensee need not be publicly disclosed, though maintaining anonymity could be difficult. Until one or more of these approaches is adopted broadly in the industry, the enforcement of the non-discrimination prong of FRAND commitments may remain happenstance, enabled primarily through the disclosure of otherwise confidential information through improper means, or in conjunction with litigation over other aspects of FRAND licensing in which potentially discriminatory activity comes to light.

\footnotetext{
${ }^{107}$ See discussion above of Gilbert's (2011) theory that non-discrimination allows ex post licensees to enjoy the same benefits as ex ante licensees.

${ }^{108}$ Carlton and Shampine $(2013,551)$ argue that "a reasonable policy is to never allow FRAND rates to rise," given that increases in FRAND rates would lead to more disputes, be hard to identify, and thereby "undermine the FRAND protection against hold-up."

${ }^{109}$ See Shampine 2016.

${ }^{110}$ Régibeau et al. 2016, 70.

${ }^{111}$ Contreras et al. 2016, Régibeau et al. 2016, 70-71, Carlton \& Shampine 2014.
} 


\section{CONCLUSIONS}

Despite a handful of litigated cases, the non-discrimination prong of the FRAND commitment has not received nearly the attention that the obligation to offer "fair" and "reasonable" royalty terms has. Nevertheless, issues of non-discrimination have become increasingly important in current disputes over FRAND licensing. While most agree that non-discrimination does not require that every potential licensee be offered identical terms, but that similarly situated parties should be offered comparable terms, broad agreement ends there. Open questions remain regarding the degree and kind of similarity that should qualify parties to comparable terms, and how comparable those terms should be, how "fairness" should be factored into the nondiscrimination determination, and how to compare non-price terms. A major question exists regarding the extent to which non-discrimination requires a SEP holder to offer licenses to all applicants, or whether it may license only certain tiers in the supply chain. Moreover, as prior generations of standards become obsolete and existing license agreements begin to expire, difficult questions will arise regarding the impact of the passage of time on non-discrimination commitments, particularly with respect to the appropriate set of licenses to which new agreements should be compared. These questions cannot be answered easily, but with luck some combination of litigation results, guidance from SDOs and greater transparency in licensing agreements will soon shed needed light on many of these questions. 